\title{
Recent patent applications in transgenics
}

\begin{abstract}
Patent \#
Subject

US 9719390

New KUZ polypeptides, members of the ADAM family of metalloprotease; useful in neural partitioning and development.

AU 977801

Iron-regulated promoter useful in site-specific chromosomal integration, especially of foreign antigen genes into chromosomes of attenuated Salmonella typhimurium strains for live vaccine production.

WO 97JP2349 Hematopoietic stem cell growth factor; useful for, e.g., treatment JP 96262252 and diagnosis of hematopoietic cell abnormalities and bone marrow inhibition.

US 9748933 Vectors containing transgene(s) encoding $\beta$-adrenergic signaling proteins; useful for gene therapy of congestive heart failure.

US 97866942 Transgenic cells for screening for regulators of gene expressioncomprise mutant of native allele encoding a reporter under control of native gene expression regulatory sequences; useful in drug screening.

US 9738685 New isolated mammalian $\beta$-defensin-1 gene(s)-used to develop products for treating microbial infections, e.g., respiratory conditions susceptible to microbial infection such as cystic fibrosis.

JP 96347090 Targeting DNA by reaction with homologous probe and recombinase-with addition of heterologous probe to increase efficiency and sensitivity; useful for in situ hybridization, gene therapy, cloning of genes, gene mapping, etc.
\end{abstract}

WO 96 US18003 Isolated toxins from Photorhabdus luminescens strains; useful US 96705484 for control of insect pests.

Assignee
Univ. California
(Oakland, CA); Yale
Univ. (New Haven, CT)

Author

Date Status

Australian Wool Res.

\& Promotion

Board; CSIRO

Kyowa Hakko Kogyo (Tokyo)

Pan D, Rooke J,

7/23/97 A1

Rubin GM, Xu T,

Yavari R

Brahmbaht THN,

$7 / 9 / 97 \quad$ A1

Burn A, Emery D

Hiraoka A, Mio $\mathrm{H}$,

$7 / 7 / 97$

Collateral Therapeutics Hammond HK,

$6 / 16 / 97$

(San Diego, CA); Univ. Gao M, Insel PA

California (Oakland, CA) Ping P, Post SR

Tularik (S. San

Francisco, CA)

Amaral MC, Chen J

$5 / 31 / 97$

de la Brousse FC,

Learned RM,

McKnight SL

Magainin Pharmaceu- Anderson M, Bals R, 2/18/97

ticals (Plymouth Meeting, Goldman M,

PA); Univ. Pennsylvania Stolzenberg ED,

(Philadelphia, PA)

Wilson JM, Zasloff M

Daikin Ind. Ltd.

(Osaka, Japan)

Kigawa K, Kusumi K, 12/26/96

Mukai E, Obata K,

Yamanaka M

Wisconsin Alumni Res. Found. (Madison, WI)

Blackburn MB, Bowen

$11 / 6 / 96$

DJ,Ciche TA, Ensign

JC, Fatig R, French-

Constant RH, Guo L,

Hey TD, Merlo DJ

Univ. Pennsylvania

Recombinant adeno-associated virus (AAV); suitable for

(Philadelphia, PA)

Fisher KJ,

$10 / 10 / 96$ e.g., dystrophin for treating muscular dystrophy.

US 9625853 New plant retrovirus SIRE-1; useful for, e.g., genetic engineering in plants.

Loyola Univ.

(Chicago, IL)

Univ. Pennsylvania

(Philadelphia, PA) cre recombinase and loxP sites; useful in genetic engineering and gene therapy.

US 9624702 Identifying antioxidant compounds for therapy using homozygous transgenic mice in which the genes encoding manganese superoxide dismutase have been inactivated.

Duke Univ. (Durham, NC); Emory Univ. (Atlanta, GA)

US 9625505 New anti-atherosclerotic peptide(s) - have an amphipathic helical mo- UAB Res. Found. tif as the structural and functional domain and mimic human apoA-I.

DE 1035917 Expression cassette protecting plants against inhibitors of adenylsuccinate synthase, which encodes microbial form of this enzyme, together with related vectors, microorganisms, and transgenic plants resistant to these inhibitors when used as herbicides.

US 96707399 DNA encoding lipid metabolic pathway polypeptide(s); useful for treatment of cardiovascular disease or modulation of lipid uptake or metabolism.

(Birmingham, AL)

BASF AG

(Ludwigshafen,

Germany)

Wilson JM

Laten HM

$9 / 9 / 96$

Phaneuf D,

$9 / 6 / 96$

Wilson JM

$9 / 6 / 96$

Crapo JD, Day BJ,

Melov SL, Wallace DC

Anantharamaiah

$9 / 5 / 96$

GM, Garber DW

9/4/96

Schiffer H, Schmidt

$R$, Sonnewald $U$

Acton S, Gimeno CJ

9/4/96

A1

Pharmaceuticals

(Cambridge, MA)

Mayo Found.

WO 96US14041Transgenic mouse susceptible to collagen induced arthritiscomprises human HLA-DQ transgene representing HLA-DQ allele associated with susceptibility to rheumatoid arthritis in humans. (Rochester, MN)

David S, Luthra S,

$8 / 30 / 96$

Zanelli E

Kaplan JM, Scaria A 8/30/96

US 9624877

Inhibiting immune response to adenoviral vectors-using antibody Genzyme to CD40 ligand present on CD4-positive T cells, particularly for treatment of cystic fibrosis; allows repeated administration of vector.

(Cambridge, MA)

Source: Derwent Information, Alexandria, VA. 'The patents in the table are pending. The status of each application is slightly different from country to country. For further details, contact Derwent Information, 1725 Duke St., Suite 250, Alexandria, VA 22314. Tel: 1 (800) DERWENT (info@derwent.com). 